\title{
The Effect of Firm's Size on Corporate Performance
}

\author{
Meiryani ${ }^{1}$ \\ Accounting Department \\ Faculty of Economics and Communication \\ Bina Nusantara University \\ Jakarta, Indonesia 11480
}

\section{Olivia $^{2}$}

Accounting Department

Faculty of Economics and Communication

Bina Nusantara University, Jakarta, Indonesia 11480

\author{
Jajat Sudrajat $^{3}$ \\ BINUS Entrepreneuship Center, Management Departement \\ BINUS Business School, Undergraduate Program \\ Bina Nusantara University \\ Jakarta, Indonesia 11480
}

\author{
Zaidi Mat Daud ${ }^{4}$ \\ Department of Accounting and Finance \\ Faculty of Economics and Management \\ Universiti Putra Malaysia
}

\begin{abstract}
The purpose of this study is to determine the effect of capital structure on firm's financial performance that is conducted on 55 manufacturing sector listed companies in Indonesia Stock Exchange. The data analysis is conducted using $R$ Studio software. Study is used data panel analysis with random effect model. The result of this study are (1) firm's size has no effect on firm's financial performance which is proxied by return-on-assets; (2) firm's size has no effect on firm's financial performance which is proxied by market-to-book-value.
\end{abstract}

Keywords-Firm size; financial performance; return on assets; market to book value

\section{INTRODUCTION}

In evaluating the company's financial performance, it can be assisted with certain measurement tools, one of which is by using profitability ratios and market ratios. Profitability ratios are ratios used to determine a company's ability to manage its assets [1]. An assessment of a company's profitability can be measured through Return-on-Asset (ROA). Return-on-assets are used to measure the effectiveness of a company in generating profits by utilizing its assets. The company's ability to utilize assets effectively and productively can generate net profit which is the result of the capital that has been invested in an asset. Return-on-assets as a form of company effectiveness in managing its assets and capital [2]. The return-on-asset measurement avoids direct comparisons with market value but relates to several factors used by market makers in their valuation of the company [3]. Return-on-assets are able to measure the company's ability to generate profits in the past and then projected in the future [4]. Company performance through profitability is one of the most important areas that is focused by shareholders and also debt holders if the company uses debt to operate [5].

Market-to-book ratios indicate investors' views on the value of the company, shares sold higher than the book value reflect good companies [6]. Therefore, the company's market value reflects how the market sees the company so that it will affect investors' valuation of the company in making its investment. One of the motivations of investors to invest their capital is return [7]. Firm's size can also affect a company's financial performance. Firm's Size is a size or scale that shows the size of a company. Firm's size can usually be seen from the company's total assets and total sales. In general, large companies will get more attention or better known to the public. The greater the size of the company can give a good signal to the public. This is in accordance with the signaling theory that the greater the firm's size will give a positive signal for the company's financial performance is getting better [8].

Research conducted by [9] in manufacturing sector companies in the country of Sri Lanka shows that there is no effect of company size which is proxied by total assets and total sales on profitability proxied by ROA and NPM.

Based on the background described above, the following are the problems identified by the researcher (then the problem can be formulated to be investigated):

1) Does Firm's Size affect corporate performance which is proxied by return-on-assets?

2) Does firm's size have a positive effect on corporate performance that is proxied by market-to-book value?

Based on this background, this study takes the title of the thesis "The effect of firm's size on firm's financial performance”.

\section{LITERATURE REVIEW}

\section{A. Signaling Theory}

Signaling theory states that there is information asymmetry or information mismatch between internal (company managers) with external parties or users of financial statements (stakeholders). With this, signaling theory explains why companies have the incentive to provide financial statement information to external parties, namely investors and creditors [10]. With the disclosure of information made by the company, users of financial statements such as investors and potential investors can make an appropriate consideration or analysis to invest their capital so as to increase market views regarding the company's financial performance. Disclosure of information carried out by company managers can give signals to users of financial statements so that accurate information is very important in the process of 
making investment decisions or providing loans by external parties. With the existence of signaling theory, it is hoped that financial statement users can obtain accurate information in order to reduce the problem of information asymmetry.

The choice of debt-to-equity-ratio indicating the quality of a company [11]. Companies by adding more debt to the company's capital structure can function as a credible signal of higher expected future cash flows. That is because the company is committed to meeting interest payments from debt holders and managing the remaining cash flow more effectively [12]. Investors consider debt issuance as a better signal than the issuance of ordinary shares because investors understand the company's management goals in issuing shares that are considered as overvalued [13]. In addition, the greater the size of the company will give a positive signal which means the company's financial performance is also getting better [14]. Signaling theory explains that to increase market views on company performance, companies have a large size or scale of companies and will increase debt.

\section{B. Firm's Size}

Firm size is a major factor in determining company profitability because of a concept known as economies of scale that can be found in the traditional view of the company [15]. It can be interpreted that companies can produce goods at a much lower cost by large companies. The size of the company is an increase in the company's employees who have a large market capitalization, and describes the size of a company. The higher the total assets that indicate the assets or assets owned by the company. Company size can be measured using total assets, sales or company capital [16]. Companies that have large total assets are considered to have good prospects in a relatively stable period and are able to generate profits compared to companies that have small total assets [17]. Large-scale companies have a higher competitiveness than small companies, because large companies have a large market so they have a great opportunity to obtain large profits [18].

\section{THEORETICAL FRAMEWORK}

\section{A. Effect of Firm's Size on Corporate Performance}

One of the factors influencing company performance (return on assets) using panel data is firm's size [19]. Companies large enough to be able to take advantage of their size to negotiate the value of their inputs and then reduce their average costs. This will result in increased profitability for the company. Intellectual capital, debt-to-equity-ratio (DER), company size, and asset turnover have positive effects while debt-to- Assets-ratio has a negative effect on ROA [19]. Based on signaling theory, the greater the firm's size will give a positive signal to the public or market which means the company has better financial performance. There is a positive and significant effect on financial performance which is proxied by ROA. He stated that the greater the assets or assets, the more capital invested, more money circulation and greater market capitalization, would improve the company's financial performance. a significantly larger firm's size and positively increased the performance of companies proxied by ROA
[20]. Based on the description above, the researchers propose a hypothesis, as follows:

Ha1: Firm size has a positive effect on firm's financial performance which is proxied by return on assets (ROA).

\section{B. Positive Effect of Firm's Size on Firm's Financial Performance (MtBV)}

Firm size can indicate that the company is experiencing growth and growth so that the market will respond positively. The greater the total assets and sales, the greater the size or scale of a company [21]. If a company has a large firm's size, then there is a possibility that it will have a better market value and financial performance compared to smaller companies [22]. Conventional banks listed on the Indonesia Stock Exchange shows that there is a positive influence on bank size on shareholder value which is proxied by market-to-book value [23]. The higher the total assets, the higher the marketto-book value. There is a positive influence on bank size with shareholder value which is proxied by market to book value. This is due to the large banks getting more attention from the public so that they are viewed more positively by investors. Based on the description above, the researchers propose a hypothesis, as follows:

Ha2: Firm size has a positive effect on firm's financial performance which is proxied by market to book value (MtBV).

\section{RESEARCH METHODOLOGY}

The data analysis method used in this study is multiple linear regression analysis techniques. Before testing on multiple linear regression methods, this method must be tested by classic assumptions to get the best results so that the data is consistent and unbiased. Types of classic assumption tests in this study are: normality test, Multicollinearity test, Heteroscedasticity test, Autocorrelation test. The regression model test using multiple linear regression analysis aims to choose the most appropriate model to be used in predicting this research. Here are some tests that can be done consisting of a chow test, the hausman test, and the lagrange multiplier test to determine which model is more appropriate in predicting the multiple linear regression equation model in this study.

\section{A. Operationalization of Variables}

Research variables are research objects that are the center of attention of researchers to be observed, studied and drawn conclusions. Variables are objects that have variations between one object and another. The variables studied were divided into two namely independent variables and dependent variables. Following is the definition and measurement of each variable will be explained as follows:

The dependent variable (or often referred to as the dependent variable) is a variable that is of primary concern to the researcher and is influenced or is due, due to the independent variables. The dependent variable in this study is corporate performance measured by profitability ratios, namely Return-on-Assets (ROA) and market ratios, Marketto-Book-Value (MtBV). 
1) Return-on-Assets (Y1): In analyzing financial statements, the ratio of the most widely used by users of financial statements is Return-on-Asset (ROA) because the ratio is able to show the company's success in generating profits. ROA is used to measure overall management effectiveness in generating profits with available assets [24]. ROA is able to measure the company's ability to generate profits in the past and then can be proxied in the future (Rosikah et al, 2018).

2) Market-to-Book-Value (Y2): Market-to-Book-Value (MtBV) is the ratio of the total market capitalization that is shared with the book value of net assets [25].

\section{B. Variable Independent}

The independent variable (or often referred to as the independent variable) is a variable that affects the dependent variable both positively and negatively. If there are independent variables, the dependent variable will also be present, and with each unit increase in the independent variable, there will also be an increase or decrease in the dependent variable. So the independent variable influences or causes the change or the emergence of the dependent variable. The independent variables used in this study are:

Firm's size is the size of a company that can be measured by assets, sales, market capitalization. Firm's size can be calculated using the following formula:

Firm's Size $=$ Ln (Total Asset)

\section{RESUlt AND DISCUSSION}

In this study, the financial statements issued by manufacturing companies listed on the Indonesia Stock Exchange (IDX) will be the object of research by researchers. After determining the research object, the sample is selected based on purposive sampling. Purposive sampling is a technique used to determine samples with a non-random sampling technique where the researcher determines sampling by setting criteria that are appropriate to the design and purpose of the study. The following is the procedure for determining the sample criteria for this research sample, as follows (Table I):

TABLE I. POPULATION SCREENING TABLE

\begin{tabular}{|l|l|l|}
\hline No. & Criteria & Total \\
\hline 1 & $\begin{array}{l}\text { The population of manufacturing companies listed on the } \\
\text { Stock Exchange during the 2014-2018 period }\end{array}$ & 152 \\
\hline 2 & $\begin{array}{l}\text { Companies experiencing delisting from the stock } \\
\text { exchange or experiencing liquidation during the 2014- } \\
\text { 2018 period }\end{array}$ & $(6)$ \\
\hline 3 & Not served in rupiah & $(28)$ \\
\hline 4 & $\begin{array}{l}\text { Does not always publish audited financial statements } \\
\text { audited financial statements) in full for periods that end } \\
\text { for 5 years in a row during the period 2014-2018 }\end{array}$ & $(14)$ \\
\hline 5 & $\begin{array}{l}\text { Manufacturing companies that suffered losses during the } \\
\text { 2014-2018 period }\end{array}$ & $(43)$ \\
\hline Amount of cross-sectional data (per year) & 61 \\
\hline Outlier & $(50)$ \\
\hline Amount of selected cross-sectional data (per year) & 11 \\
\hline Research period 2014-2018 (time-series data) & 5 tahun \\
\hline Number of samples selected (total panel data) & 55 \\
\hline
\end{tabular}

Source: www.idx.co.id and processed
Through this screening process, 305 companies (61 crosssectional data with 5 years' time-series data) were obtained on the Indonesia Stock Exchange which were allowed to be selected as samples. By using a confidence level of $95 \%$ to obtain an error rate of 5\%. Furthermore, the authors screened outlier data based on box plot observations and standardized scores (z-scores) with a value of $\geq 2.5$ which were declared as outliers so that 55 panel data were obtained that would be used for the five-year study period from 2014-2018, consisting of combined 11 cross-sectional data and 5 time series data.

\section{A. Research Data Collection}

Most of this research uses numbers contained in accounts that appear on financial statements. The following will explain how researchers obtain these numbers:

a) Total Assets is a symbol of the position of total assets in the current period. In the Statement of Financial Position presented comparatively, the author will use the numbers on "Total Assets" as at 31 December in the current year period;

b) Market Price is a symbol of the market price of shares in each company obtained using the Close figure every December 31 Historical Data section contained on the website www.finance.yahoo.com.

c) Number of Outstanding Shares is a symbol of the number of shares outstanding during the period. If a company has Treasury Shares, then those shares must be excluded from the calculation of the number of shares outstanding because the number of shares outstanding is shares circulating to the market or the public that are not shares that were recovered by the Company. In the Statement of Financial Position of the Equity section presented comparatively, the author will use the number of shares written on "Issued and fully paid share capital" as of December 31 and reaffirm the Notes to the Report Finance (Notes to the Financial Statements) by looking at the number of shares outstanding by subtracting the numbers on the "Treasury Shares" as of December 31 in the current period;

d) Firm's Size is the size of the company with the natural logarithm symbol of total assets in the current period. In the Statement of Financial Position presented comparatively, the author will use the numbers on "Total Assets (Total Assets)" as of December 31, which will then be performed natural logarithms.

\section{B. Research Data Calculation}

After getting all the data needed, then some calculations will be performed to get the desired information:

a) To meet the regression equation used, the researcher will do a regression model to find the estimated coefficients of each variable;

b) Return-on-Assets are calculated by dividing Net Income After Tax by Total Assets as ROA variable;

c) Market-to-book value is calculated by dividing Market Value with Book Value as an MtBV variable. Market Value is obtained by multiplying Market Price by Outstanding Number of Shares and Book Value is obtained by subtracting Shareholder's Equity with Paid in capital; 
d) Firm's Size is obtained from total assets which then the logarithm of its natural search is called Ln (Total Assets).

\section{Descriptive Statistical Analysis}

Descriptive statistical analysis aims to provide an overview of the data used in this study. Descriptive statistics consist of minimum values, maximum values, mean values, and standard deviations of each variable (Table II).

Descriptive statistical analysis aims to provide an overview of the data used in this study. Descriptive statistics consist of minimum values, maximum values, mean values, and standard deviations of each variable. In these results, $n$ indicates the number of samples for each variable used in this study. Mean is the average value of research data. Standard deviation is a measure of the spread of data used to measure the amount of variation or distribution of a number of data values. Standard deviation is a large difference from the sample value to the Mean. The lower the standard deviation, the closer it will be to the average value, whereas if the standard deviation value is higher, the wider the variation of the data range. Maximum is the highest value of the amount of data analyzed. Minimum is the lowest value of the amount of data analyzed.

Descriptive statistical tests consist of ROA (Return-onAsset) and MtBV (Market-to-Book-Value) as the dependent variable. The number of sample data used in the calculation of descriptive statistics is the entire sample data, which is 55 data. Return on Assets (ROA) is the first dependent variable that measures a company's profitability based on information contained in the company's financial statements. ROA has an average value of 0.08 ; which means that the ability of companies to get profits from their assets is 0.08 or $8 \%$. ROA has a standard deviation value of 0.04 which means that the level of size distribution of ROA variable data is 0.04 . The lowest and highest value of ROA is 0.02 and 0.16 , respectively in PICO companies in 2018 and BATA in 2015. That is, BATA is a company that is able to generate profits by managing its assets effectively while PICO is a valued company less able to effectively generate profits by managing the assets they have.

Market-to-Book-Value (MtBV) is the second dependent variable that measures a company's market value based on information provided on the market and the company's financial history. MtBV has an average value of 1.71 with the lowest and highest values of 0.29 and 4.63 respectively in PICO companies in 2015 and STTP in 2014. Based on market or public views, stakeholders will be interested in investing in an company when the company reflects good performance so that the stock price will show a higher price and have a relatively lower additional paid in capital because the stock is sold not to overprice from face / nominal value. That is, STTP is a company deemed to have an appeal by the market or the public which is reflected in the stock price of Rp. 2,880 with a total of circulating shares of $1,310,000,000$ shares, whereas the opposite is for PICO with having a stock price of Rp 128 with a total number of outstanding shares of 568,375. 000 sheets.
TABLE II. DESCRIPTIVE STATISTICAL ANALYSIS

\begin{tabular}{|l|l|l|l|l|l|}
\hline & N & Minimum & Maximum & Mean & $\begin{array}{l}\text { Std. } \\
\text { Deviation }\end{array}$ \\
\hline ROA & 55 & 0,02 & 0,16 & 0,08 & 0,04 \\
\hline MtBV & 55 & 0,29 & 4,63 & 1,71 & 1,05 \\
\hline $\begin{array}{l}\text { Firm's } \\
\text { Size }\end{array}$ & 55 & 26,57 & 30,40 & 27,93 & 1,15 \\
\hline
\end{tabular}

Source: R Studio Application Processing Results

Firm's size is one of the independent variables from a sample of banking companies. Firm's size is calculated from the logarithm of the company's total assets. The average value of the firm's size shows an average value of 27.93. The standard deviation of the company size is 1.15 with the lowest value of 26.57 which is the ALDO stock code in the 2014 period, while the highest value is 30.40 , which is AUTO in 2018, which means AUTO has the largest company size compared to with manufacturing sector companies listed on other Indonesian Stock Exchanges measured by the logarithm value of total assets of banking companies while company size on ALDO has the smallest company size compared to manufacturing sector companies listed on other Indonesian Stock Exchanges in 2014-2018 measured from natural logarithm value of total assets.

\section{Estimation of the Regression Model Coefficient}

The multiple linear regression model used to estimate ROA (Return-on-Asset) and MtBV (Market-to-Book-Value) is carried out in a panel by combining 11 cross-sectional data multiplied by 5 years of the 2014-2018 research period so that 55 observation (Table III).

TABLE III. REGRESSION MODEL COEFFICIENT ESTIMATION RESUlTS

\begin{tabular}{|l|l|l|l|}
\hline Independent Variable & & Expected Sign & ROA \\
\hline Intercept & Coeff. & - & $-2,706223$ \\
\hline FIRM'S SIZE & Coeff. & + & 1,077067 \\
\hline \multicolumn{3}{|c|}{ Source: R Studio Application Processing Results }
\end{tabular}

The estimated coefficient of -0.242502 can be interpreted that ROA will have a value of -0.242502 if the DER variable has a value equal to 1 , and the other independent variables are constant or can be interpreted as each DER increase of 1 unit will decrease ROA by -0.242502 . While the negative sign (-) indicates the opposite relationship between the DER variable with ROA; and the estimated coefficient of 1.077067 can be interpreted that ROA will have a value of 1.077067 if the Firm's Size variable has a value equal to 1 , and the other independent variables are constant or can be interpreted as each Firm's Size increase of 1 unit will increase ROA by 1.077067. While the positive sign $(+)$ indicates a direct relationship between the Firm's Size variable and ROA [28].

\section{E. Partial Test of Regression Model 2}

In this section, we will show the partial test results on the MtBV (Market-to-Book-Value) multiple linear regression equation, as follows (Table IV): 
TABLE IV. PARTIAl TEST ResUlt OF REgRESSION MOdEl 2

\begin{tabular}{|l|l|}
\hline Uji Parsial & Sig. \\
\hline DER & 0,69437 \\
\hline FIRM'S SIZE & 0,32109 \\
\hline \multicolumn{2}{|c|}{ Source: R Studio Application Processing Results }
\end{tabular}

Based on the partial test results, namely, z-test statistics, the following conclusions can be obtained:

Firm's Size variable has the result of a significance value (Sig.) Of 0.32109; where the value is greater than 0.05; thus indicating that the independent variable Firm's Size does not significantly influence the MtBV dependent variable [30].

\section{F. Discussion}

1) Firm's Size influences Return-on-Asset: Based on the hypothesis carried out in the previous chapter, the first hypothesis proposed in this study is as follows:

Ha1 = Firm's Size has a positive effect on Return-onAssets.

Firm's Size variable produces a significance value of 0.17367 ; which means that the significance value is greater than 0.05 then Firm Size does not have a significant effect on ROA (Return-on-Asset). While the coefficient value of the Firm's Size variable regression model for ROA (Return-onAsset) is 1.077067. Therefore, it can be concluded that the Firm's Size variable has no significant and positive effect on ROA (Return-on-Asset) with a 95\% confidence level. So from testing this hypothesis, Ha is rejected and HO is accepted.

The results of this study are also supported by the research of [29] which shows that firm's size does not affect company performance consisting of return-on-assets, market-to-bookvalue or tobin's q. This is because the firm's size measured by the natural logarithm of the total assets does not reflect the actual value of the assets so the firm's size cannot be a guarantee of good company performance.

2) Firm's Size affects Market-to-Book-Value: Based on the hypothesis carried out in the previous chapter, the 8th hypothesis proposed in this study is as follows:

Ha2 = Firm's Size has an influence on Market-to-BookValue.

Firm's Size variable produces a significance value of 0.32109 ; which means that the significance value is greater than 0.05, Firm Size does not have a significant effect on MtBV (Market-to-Book-Value) and has a positive effect based on the sign of the Firm Size Variable regression model coefficient which is equal to 3.43163. Therefore, it can be concluded that the Firm's Size variable does not have a significant positive effect on MtBV (Market-to-Book-Value) with a 95\% confidence level. So from testing this hypothesis, $\mathrm{Ha}$ is rejected and HO is accepted.

Based on the results of the study, it can be interpreted that the firm's size variable does not support signaling theory which states that the greater the size of a company can improve the company's financial performance. The reason why firm's size does not have a significant positive effect on
MtBV (Market-to-Book-Value), because the public does not see the size of the manufacturing sector in Indonesia as a determinant of the success of a company's performance [26].

There are several reasons why firm's size does not have a significant positive effect on MtBV (Market-to-Book-Value) because even though large-sized companies have relatively large assets, they may not necessarily explain high returns to shareholders [27].

\section{CONCLUSION}

Based on the results of the rainfall and the discussion carried out, a number of conclusions is obtained, as follows:

1) Based on the test results, firm's size has no effect on firm's financial performance which is proxied by return-onassets.

2) Based on the test results, firm size does not affect firm's financial performance which is proxied by market-tobook-value.

\section{ACKNOWLEDGMENT}

Thanks to BINUS University Jakarta Indonesia.

\section{REFERENCES}

[1] Aghekyan-Simonian, M., Forsythe, S., Kwon, W. S., \& Chattaraman, V. (2012). The role of product brand image and online store image on perceived risks and online purchase intentions for apparel. Retailing and Customer Services, 325-331.

[2] Alawad, A., Aljoufie, M., Tiwari, A., \& Daghestani, L. (2015). Beyond Geographical and Cultural Barriers: The Concept of a Virtual Gallery for Arts, Design \& Architecture Schools in Saudi Arabia. Art and Design Review, 87-93.

[3] Att Petcharit, Puris Sornsaruht, Paitoon Pimdee. (2020). An Analysis of Total Quality Management (TQM) within theThai Auto Parts Sector. Vol 16, No 02 (2020). International Journal of Online and Biomedical Engineering.

[4] Arshi Naim, Fahad Alahmari. (2020). Reference Model of E-Learning and Quality to Establish Interoperability in Higher Education Systems. Vol 15, No 02 (2020). International Journal of Emerging Technologies in Learning.

[5] Abeywardhana, D. K. Y. (2016). Impact of Capital Structure on Firm Performance: Evidence from the Manufacturing Sector of SMEs in the UK. SSRN Electronic Journal.

[6] Ahangar, R. G. (2011). The relationship between intellectual capital and financial performance: An empirical investigation in an Iranian company. African journal of business management, 5 (1), 88-95.

[7] Alusia, Y. H. \& Pangestuti, I. R. D. (2015). Analysis of the Effect of Non-Performing Loans, Investment Proportion, Loan To Deposit Ratio, Liability to Equity Ratio and Bank Size Against Shareholder Value in Conventional Banks Listing on the Indonesia Stock Exchange in 2011 to 2014. Diponegoro Journal of Management, 4 (4), 1-9.

[8] Ashraf, M., Ameen, A., \& Shahzadi, K. (2017). The Impact of Capital Structure on Firm's Profitability: A Case of Cement Industry of Pakistan. International Journal of Business and Social Science, 8 (4), 140-147.

[9] Atidhira, A.T. \& Yustina, A.I. (2017). The Influence of Return on Assets, Debt to Equity Ratio, Earnings per Share, and Company Size on Share Returns in Property and Real Estate Companies. JAAF (Journal of Applied Accounting and Finance), 1 (2), 128-146.

[10] Azzahra, A. S. \& Fate. (2019). Effect of Firm Size and Leverage Ratio on Financial Performance in Mining Companies. JWEM STIE MICROSCIL, 9 (1), 13-20.

[11] Azhar Susanto \& Meiryani. 2019. The Quality of Accounting Information system and its impact on the quality of accounting information: user ability and top management support. Journal of Engineering and applied sciences 13(2), pp. 384-387. 
[12] Azhar Susanto \& Meiryani. 2019. Antecedents of environmental management accounting and environmental performance : Evidence from Indonesian small and medium enterprises. International Journal of Energy Economics and Policy. 9(6), pp. 401-407.

[13] Central Statistics Agency (2018). Indonesia Gross Domestic Product Quarterly 2014-2018. ISSN: 1907-4557, No. Publication: 07130.1803.

[14] Bchini, B. (2015). Intellectual capital and value creation in the Tunisian manufacturing companies. Procedia Economics and Finance, 23, 783791.

[15] Indonesia stock exchange. (2019). Financial and Annual Report. Retrieved October-November-December 2019, from the Indonesia Stock Exchange: www.idx.co.id

[16] CIMA (2003). Understanding Corporate Value: Managing and Reporting Intellectual Capital. Carnfield University School of Management. UK

[17] Chen, M. C., Cheng, S. J., \& Hwang, Y. (2005). An empirical investigation of the relationship between intellectual capital and firms' market value and financial performance. Journal of intellectual capital, 6 (2), 159-176.

[18] Darmawan, M. \& Toro, J. S. (2012). The Impact of Intellectual Capital on Banks Go Public's Market Value and Financial Performance Listed in Indonesia Stock Exchange (IDX). Managerial Focus, 11 (2), 164 - 182.

[19] Devi, B. E., Khairunnisa, \& Budiono, E. (2017). Effect of Intellectual Capital on Company Financial Performance. e-Proceeding of Management, 4 (1), 491-500.

[20] Dey, R. K., Hossain, S. Z., \& Rahman, R. A. (2018). Effect of Corporate Financial Leverage on Financial Performance: A Study on Publicly Traded Manufacturing Companies in Bangladesh, Asian Social Science, 14 (12), 124-133.
[21] Dewi, Y. T. \& Hatane, S. E. (2015). The Role of Employee Stock Ownership Plans in the Effect of Intellectual Capital Value Added on Financial Performance. Business Accounting Review, 3 (1), 478-488.

[22] Dwipayani, C. C. \& Prastiwi, A. (2014). Effect of Intellectual Capital on Profitability and Market Performance. Diponegoro Journal of Accounting, 3 (3), 1-9.

[23] Egbunike, C. F. \& Okerekeoti, C. U. (2018). Macroeconomic factors, firm characteristics and financial performance, Asian Journal of Accounting Research, 3 (2), 142-168.

[24] Fu, X., Lin, Y., \& Molyneux, P. (2014). Bank Efficiency and Shareholder Value in Asia Pacific. Journal of International Financial Markets, Institutions \& Money, 33, 200-222.

[25] Ghozali, I. (2013). Application of Multivariate Analysis with SPSS 21. Diponegoro University. Semarang.

[26] Ghozali, I. (2016). Multivariate Analysis Application with SPSS Program. Semarang: Diponegoro University Publisher Agency, Semarang.

[27] Gitman, L. J. \& Zutter, C. J. (2015). Principles of Managerial Finance. Fourteenth Edition. United States of America: Pearson.

[28] Godfrey, J., Hodgson, A., Tarca, A., Hamilton, J., \& Holmes, S. (2010). Accounting Theory. Milton, Qld .: John WIley \& Sons, Inc.

[29] Gupta, N. K. \& Gupta, H. (2014). Impact of Capital Structure on Financial Performance in Indian Construction Companies. International Journal of Economics, Commerce and Management United Kingdom, 2 (5), 1-14.

[30] Harjito, D. A. (2011). Pecking Order Theory and Trade-Off in Capital Structure Asnalysis on the Indonesia Stock Exchange. SIASAT BUSINESS, 15 (2), 187-196. 109. 